\title{
Waardering van bewijs
}

Citation for published version (APA):

Elders, J. L. M. (1990). Waardering van bewijs: Afscheidsrede door Prof. Mr. J.L.M. Elders. (1 ed.) Kluwer. https://doi.org/10.26481/spe.19900427je

Document status and date:

Published: 27/04/1990

DOI:

10.26481/spe.19900427je

Document Version:

Publisher's PDF, also known as Version of record

\section{Please check the document version of this publication:}

- A submitted manuscript is the version of the article upon submission and before peer-review. There can be important differences between the submitted version and the official published version of record.

People interested in the research are advised to contact the author for the final version of the publication, or visit the DOI to the publisher's website.

- The final author version and the galley proof are versions of the publication after peer review.

- The final published version features the final layout of the paper including the volume, issue and page numbers.

Link to publication

\footnotetext{
General rights rights.

- You may freely distribute the URL identifying the publication in the public portal. please follow below link for the End User Agreement:

www.umlib.nl/taverne-license

Take down policy

If you believe that this document breaches copyright please contact us at:

repository@maastrichtuniversity.nl

providing details and we will investigate your claim.
}

Copyright and moral rights for the publications made accessible in the public portal are retained by the authors and/or other copyright owners and it is a condition of accessing publications that users recognise and abide by the legal requirements associated with these

- Users may download and print one copy of any publication from the public portal for the purpose of private study or research.

- You may not further distribute the material or use it for any profit-making activity or commercial gain

If the publication is distributed under the terms of Article $25 \mathrm{fa}$ of the Dutch Copyright Act, indicated by the "Taverne" license above, 


\section{WAARDERING \\ VAN \\ BEWIJS}

\section{AFSCHEIDSREDE}

gehouden aan de Rijksuniversiteit Limburg te Madastricht op vrijdag 27 april 1990

door

PROF.MR.J.L.M. ELDERS 
ISBN 9026820038

19Prom, J.L.M. Elders. 1990

Behoudens uizondering door de Wet gesteld mag zonder schrifelijke toestemming van de rechthobbende(n) op het auteurswech, c.q. de uigeefster van deze uitgalve, door de rechthebbendo(n) gemahtigd manens hem (hen) op te treden, nieis uit deza uigave worden verveelvoudigd en/of openbata gemak door middel van druk, fotokopic, microlilm of anderszins thetgeen ook van toepassing is op de gehele of gedeeltelijke bewerking.

De vitgeester is met uitshiting van ieder ander gerehtigd de doog derden verschuldigde ver goedingen van kopièrew, bedoeld in artikel 17 hid 2, Autcurswet 912 en in het K.B. van 20 juni 1974

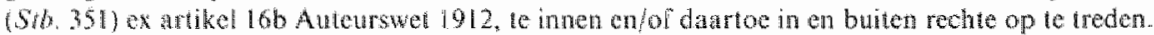


Mijnheer de voorzitter van hei College van Bestuur, mijnheer de rector, dames en heren.

Het onderwerp waarvoor ik heden Uw andacht wil vragen, te weten wardering van bewijs' vormt een van de kemprobiemen wan ons procesrecht. Het gast hierbij immers om de vaststelling van de feiten hetzij in het strafproces, het burgerlijk proces, of het administratiof proces. Daarbij rijzen vagen als "wat is bewijzen in het recht", en "in hoeverre is de rechter wrij dan wel behoort hij vrij te zijn in zijn waardering van het hem voorgelegde bewijs".

Het antwoord op deze vragen is niet voor alle rechtsgebieden gelijluidend. hetgeen samenhangt met de rechtspositie van de betrokken procespartijen. Terwijl in het strafproces en het administratief proces de burger als procespartij tegenover de overheid staat, is er in het burgerlijk proces in beginsel sprake van volstrekte gelijkheid van partijen, ook daar waar de overheid procesparij is.

Als gevolg van de partijautonomie in het privaatrecht is de burgerlijke rechter in sterkere mate lijdelijk dan de rechter in het straf- of administratief proces. Daarmee houdt verband dat niet het onderzoek naar de materiële warheid in het burgerlijk proces voorop staat, maar het vaststellen van de processucle watheid. En het is deze waarheidsvinding in het burgerlijk proces en met name de betekenis van de bewijswatdering door de rechter in dit verband die het eigenlijke onderwerp van deze oratie vormt.

Nog altijd is van belang hetgeen Eggens over hed begrip bewijs in het burgerlijk proces heeft opgemerkt. Procespartijen, aldus Eggens, staan tot elkaar in een privaatrechtelijke verhouding. Het bestaan van een rechtsbetrekking betekent niet anders dan dat zij geldt. Uiteindelijk bepaalt de rechter de rechtsbetrekking tussen partijen zoals hij die ziet. Daarbij heeft hij rekening te houden met de door partijen ingenomen standpunten. De rechter maakt niet uit of iemand eigenaar is maar of hij als zodanig heeft te gelden tegenover de wederpartij.' Het procesrecht is derhalve een wereld op zich zelf.

Het gat in he procesrecht alleen om reten die ligdens het geding fer kenn is wh de rechter komen en die volgens de regels van de procedure komen vast te stan. Feiten die door een verweerder voor het eerst in hoger beroep worden gesteld in strijd met een in eerste aanleg gevoerd verweer, ook al zijn de naderhand gestelde feiten juist, gelden als gedekt en kunnen door de rechter in beroep niet in aanmerking genomen worden.

De omschrijwing van Anema, dat het doet van het burgerlijk geding is het verkrijgen van een met gezag beklede bindende uispratak wan juridische en mitsdien ethische aard, komt nog altijd juist voor. ${ }^{3}$

Deze uitspraak moet worden gegeven op de grondslag van ten processe angevoerde en vaststaande reiten voor zover deze een bepaalde beslissing kunnen dragen. 
Anders gezegd, het gad niet om blote feiten maar om juridisch kwallificerbare feiten die verband houden met de rechtsbetrekking in geschil. Het doel van het juridisch bewijs is tot een rechtsbeslissing te komen die aran de hand van hetgeen in de procedure is komen vast te staan volgens de daarvoor geldende tegels behoorlijk gemotiveerd kan worden.

De vaststelling van feiten vindt allereerst plaats op grond van het debat tussen partijen volgens het beginsel van eis en tegenspraak. Kan op grond van de aldus door de rechter vastgestelde feiten reeds een eindbeslissing worden gegeven, dan kom men aan bewijslevering niet meer toe. Toch zou het onjuist zijn om te menen dat bewijsregels hierbij geen rol spelen. Gestelde feiten die niet of onvoldoende zijn weersproken staan tussen partijen vast. Maar de constatering van de rechter dat een stelling onvoldoende is weersproken bewat reeds een element wan bewijswaardering. Allereerst de vaststelling dat de stelling watrom het gaat op zich niet onaannemelijk is. Dat is dus het uitspreken wan cen ervaringsoordeel. Vervolgens de rechtsbeslissing dat er sprake is van onvoldoende betwisting. Een dergelijke beslissing houdt reeds een waardering in van de rechtswerhouding tussen partijen en bevat met name het oordeel dat bijw, de verweerder in de gegeven juridische situatie niet kan volstaan met hetgeen hij heeft gesteld.

Een en ander vormt mijns inziens een illustratie wan de juistheid van de opvatting van Eggens dat het in het civiele proces gaat om de vaststelling van een rechtsbetrekking.

In deze opvatting bestaat er geen principieel verschil tussen wat Gerbrandy heeft genoemd het stadium van de bewering en het stadium van het bewijs. "Voor het beweringsstadium zo begrijp ik Gerbrandy zou geen waarheidsplicht voor partijen gelden, doch voor het bewijsstadium wel. Ik acht deze opvatting onjuist, ondat het immers in beide stadia om dezelfde rechtsbetrekking gaat. In de moderne procesgang wordt door middel van de comparitie van partijen na antwoord getracht het geschil bespreekbaar te maken en zo er al geen minnelijke schikking mogelijk is, tracht de rechter toch op onderdelen geschilpunten uit de weg te rumen. Ook zonder dat men een waarheidsplicht voor partijen aanneemt kan gesteld worden dat het opzettelijk misleiden van de wederpartij en/of de recher in ieder geval strijdig is met de beginselen van een behoorlijke procedure. Wel is juist dat er voor procespartijen ten opzichte van elkaar in beginsel geen mededelingsplicht bestaat. Het duidelijkst blikt dit uit de omstandigheid dat de partij-getuige, hoewel hij in vrijwel ieder opzicht met de gewone getuige is gelijkgesteld, niet gedwongen kan worden tot spreken; anders gezegd een partij is niet verplicht tegen zich zelf bewijs te verschaffen, een beginsel dat correspondeent met art. $29 \mathrm{~Sv}$.

Warheid spreken in het recht, aldus Gerbrandy, is zodanig spreken dat de ander, lot wie de woorden gericht zijn, er op vertrouwen kan.

Het is derhalve een relationeel begrip binnen een bepalde context, niet een absoluut begrip. Mar men kan dit ook anders uitdrukken. Het gaat in het recht 
niet om waarheden mar om waarden, met name door het recht beschermde belangen.

Hiemee is een eerste relatwering gegeven in die zin dat rechtsregels geen waatheidspretentie hebben maar dat zij een zin veronderstellen.

Op deze relativering van de rechtsregel volgt een weede relatiwering en wel die wan het begrip bewizen in het recht. Het grote verschil tussen bewijzen in het recht en bewijzen in de naturwetenschappen, aldus Drion, is het verschil in doelstelling. Het doel van het juridisch bewijs is tot een beslissing to komen waaraan rechtsgevolgen zijn verbonden. Het karakter van deze rechterlijke beslissing is dat zij definitief is en dat zij op redelijke gronden verdedigd moet kunmen worden. Worden te hoge eisen gesteld aan de overtuigingskracht van de bewijiswoering, dan word de wederpartij van de bewijsplichtige bevoordecld wordt het bewijs al te gemakkelijk angenomen dan is het omgekeerde het geval.

Juist het defmitieve karakter van de beslissing, aldus Drion, kan meebrengen dat een grotere mate van overtuigingskracht wordt geeist, al naar mate de gevolgen van de rechterlijke beslissing dieper ingrijpen in de belangen van de procederende partijen. Een voorbeeld kan dit verduidelijken. In een procedure moest de eiser bewijzen dat tussen hem en de gedaagde een koopovereenkomst tot stand was gekomen waarbij eiser zijn grote boerderij voor zen anzienlijk bedrag aan gedaagde had verkocht. Als enige getuige werd eisers makelaar gehoord die namens eiser de onderhandelingen had gevoerd met de gedaagde. Deze getuige verklaarde conform de bewijsopdracht. Eiser bood aan een aanvullende eed af te leggen. De procedure speelde rond 1975, dus onder het vorige bewijstecht toen een aanvullende eed mocht worden opgelegd aan de bewijsplichtige die een begin van bewijs had geleverd. De rechtbank liet eiser echter niet toe tot het afleggen wan een aanvullende eed en wees de vordering als onbewezen af. De ratio van deze beslissing was dat, nu de gehoorde getuige tevens belanghebbende was, diens betrokkenheid bij de uitkomst van de procedure zodanig was dat het niet verantwoord leek een zo ver strek kend rechtsgevolg als een wederkerige overeenkomst in beginsel aan te nemen enkel op grond van éen door de wederpartij betwiste verklaring. De rechtbank achtte derhalwe onvoldoende bewijs geleverd om eiser toe te laten tot een aanvultende eed. Deze bewijswardering hicld verband met de overweging dat een toewijzing van de vordering voor gedaagde veel ingripender gevolgen zou hebben dan een afwijzing voor eiser.

Een illustratie van de opvatting dat, natamate de rechtsgevolgen van een beslissing ernstiger zijn, de eisen aan het bewijs te stellen dienovereenkomstig hoger dienen te zijn, vinden wij in het strafrecht war cen dubbele eis wordt gesteld, te weten een minimum an wettelijke bewijsmiddelen gevoegd bij een positieve overtuiging wan de rechter.

In het burgerlijk recht stelt de wet in het algemeen, met name in het niewwe bewijsrecht, geen minimumeisen behoudens met betrek king tol de verklaring van de partij-getuige zoals wij nog zullen zien. 
De enige. zij het net wetletije, regel die men in dit verband zou kunnem noemen is de regel dat de te bewijzen feiten meer aamenelijk moeten zijn dan het tegendeel, cen regel die in de Common Law-landen bekend is als "the preponderance of zidence:

Aan de regeling vam ons bewijsrechu ligt de gedachte ten grondslag dat in bewijkswesties aan de rechter een grote vrijheid moet worden gelaten, maar hat probleem dat zich hierbij voordoet is of an deze wrijhcid van de rechter grenzen zijn gesteld en zo ja, hoe men deze grenzen kan bepalen zonder de voordelen van het stelsel weer prijs te geven.

Bif de parlementaire behandeling van wetswoorstel 10377 zijn door de vaste commisse an de minister in deze geest vragen gesteld, een en ander tegen de achtergrond wan de vrees dat de voorzienbaarheid van rechterlike beslissingen door de voorgestelde regeling onvoldoende zou worden gewaarborgd. Het antwoord van de minister hield in dat de vrijheid van de rechter bij de watardering van het bewijs slechts kan functioneren binnen de beperkingen die woortvloeien uit diens lijdeligkheid.

Bij het vraagstuk van de begrenzing van de rechterlijke wrijheid, aldus de mimister, dienen twee min of meer tegengestelde belangen te worden afgewogen. enerzijds het winden van de materiele waarheid wartoe slechts bij uitzondering aan de rechter bindende voorschriften met betrek king tot de waardering van het bewijs dienen le worden gegeven, anderzijds de rechtszekerheid woor procespartijen, hierin gelegen dat zij hun procesrisico vooraf zo veel mogelijk kunnen bepalen aan de hand van de wettelijke bewijskracht van voorhanden zijnde bewijsmiddelen.

In hoevere vomt nu de regel van de vrije bewijswaardering door de rechter een evenwichtige oplossing van de spanning tussen waarheidsvinding en rechtszekerheid? Datartoe dient nader te worden ingegaan op de inhoud wan de artt. 176 tot en met $180 \mathrm{Rv}$.

In art. $176 \mathrm{R}$ wordt de cis gesteld dat de rechter slechts die feiten of rechten aan zijn beslissing ton grondslag mag leggen die in het geding te zijner kemis zijn gekomen of gesteld en dic overeenkomslig de regels zijn komen vast te staan. Feiten vin algemene bekendheid en algemene ervaringsregels mogen steds aan de beslising ten grondslag worden gelegd en behoeven geen bewijs. Onvoldoende legenspraak of erkenning kan echter niet leiden tot een rechtsgevolg dat niet ter wrije bepaling wan partijen statat.

Art. 176 Rv bevat dus in zovere een eerste beperking van de wrijheid wan de vechter dat deze bij de waardering van het bewijs gebonden is aan datgene wat in de procedure an de orde is geweest. Hij mag dus bij de bewezen verklaring en de waandering van bewijs niet lenggrijpen naar bewijsgronden die buiten de procedure zijn gelegen, tenzij voor zover het feiten van algemene bekendheid betreft of algemene ervaringsregels.

Samenvaltend: de eerste vaag warvoor de rechter word gesteld is die in 
hoevere de voor de gevragde beshssing relevate foten reds vaststan. danwel in hoeverte ex bewishem moet worden geformuleerd. Ook in deze fase is ar sprake van bewiswardming met betrekking tot de way of er al dan not voldoende tegensprak is en welke feiten voor de beslissing retevan zijn.

Een tweedeprealabale beperking wan de wijheid van de rechter bij de warda ring wan het bewijs is de wag naar de toelaabaatheid van het bewijnmidel en de vraag of er sprake is van onrechtmatig verkregen bewijs.

Wat de Loelatbarhet van bewijsmidelen in burgerlyke zaken betreft, is er in beginsel geen enkele beperking. tenzij de wet een bepadd middel uitshit. $A r i .179$ Rv bepaat dit met zoveet woorden. Dit betekent dat in het nieuwe bewijstent en zulks in overenstemming met de reeds onder het oude bewigrech gegroede praklik, natast de traditonele bewijmiddelen ook techische produkten als foto's, fims, dia's, video-en geludsbanden, ook woor zover zij net als geschrift gelden, als bewijsmateriaul kunnen worden gebrukt. De regel een getuge-geen getuige" (ar. 1942 oud BW) is vervallen en wit de parlementaite behandehing blijkt, met name uit de afwizing door de minister van een datrtoe strek kend woorstel van D'66 in de viste commissie? dat voor het annemen van het bewijs zelfs én bewijsmiddel mat vrije bewijkracht voldoende kan zijn. De minister bezigde als agument dat geen beperkingen van de vrijheid van bewighatadering moesten worden ingevoend die in het onderwerp nu juist waren afgeschafi." $\mathrm{K}$ kom hierop nog terug.

Nu ziner een antal rechtsguren warbij de wet de eis stelt wh een geschrif. Zo is bij schenking ingewolge art. 1703 BW een notariète akte vereist, zo kan het bewijs van as breng ten huwelik van buiten de geneenschap gehouden goedoren slechts bewezen worden door vermelding in de akte van huwelijkse woorwarden of in een an die akte gxhechte beschrijing. 20 moet volgens art. $255 \mathrm{~K}$ de overeenkomst van verzekering schriftelijk worden a angegaan. Datzelfdo geldt voor de hutrkopovereenkomst en bepalde bedingen bij de arbeidsovereenkomst. De rechter is in deze gevallen dus niet wrij om het bewijs op grond van andere bewismiddelen wan te nemen.

Voor zover de betrefonde wetsbepalingen dudelijk zijn. ontstat ar goen probleem. Veet moenliker is echter de vaag naar went uele on rechmatigheid van bewijs in de civielnechtelige procedwre. Daarbij geldt, het is al ecrdor opgenerki, dat de theoric omtrent de geoorloofdheid van het gebruk in het strafproces van onrechmatlig verkregen bewiss net zonder mea bruikbat is in het burgerligk process.

Men moet her nar min mening onderscheiden lussen gebrekkig bewijs, dat wil zeggen bewijs dat door middel van misdrijf is ontstan, zoals bjy. een onder bedreiging algelegde verklaringen bewigs dat op zich zell niet gebrekkig is, mat dat hetzij op onrechtmelige wijze in het bezil is gekomen van de wederparti. hetzij in strijd met de wet, bijv. bij schending van een beroepsgehem, dan wel door handelen in strjo met een tussen partijen geldende overeenkomst. 
De rechter stat hier vak voor een moeilijke beslissing waarbij hij de onrechtmatigheid van het gebruk van het gewrakte bewijsmiddel moet afwegen tegen het belang van de warkeidsvinding. Voorop stat daarbij de beslissing of er wel van een wettig bewijsmiddel sprake is hetgeen uiteraard een waarderingsoordeel insluit.

In een weetal vrij recente arresten heeft de Hoge Raad aangegeven met welke omstandigheden de rechter hier rekening heeft te houden. ${ }^{10}$

In het cerste geval ging het om een geschil tussen echtgenoten. De man had een codicil opgesteld en in een enveloppe opgeborgen, welk stuk tegen de bedoeling van de man in handen van de vrouw was gekomen. In een procedure tussen partijen wegens een door de man over het vermogen van de vrouw gevoerde betheer wilde de vrouw dit codicil gebruiken als bewijsmiddel, waarna de man in kort geding afgifte eiste, stellende dat zijn vrouw in de procedure van dit stuk geen gebruik mocht maken. In hoger beroep besliste het Hof " $s$-Gravenhage dat, nu het om een door de man eigenhandig geschreven verklaring ging die in een enveloppe was gesloten warop in zijn handschrift "codicil" stond vermeld, gevolgd door zün naam, een en ander op zich zelf reeds meebracht dat de vrouw dit stuk niet tegen de wil van de man onder zich mocht houden en zij de daarin vervatte verklaring niet voor enig bewijs tegen de man mocht gebruiken, ongeacht de vraag of het stuk op grond van gemeenschappelijk overleg tussen partijen was tot stand gekomen en met welke bedoelingen zulks was geschied. De Hoge Raad casseerde met de overweging dat, wanneer een stuk op grond van gemeenschappelijk overleg tot stand is gekomen, aard en strekking van dat overleg bepalend zijn voor de rechten die partijen over en weer ten aanzien van dat stuk kumnen doen gedden.

Anders gezegd, de vraag of een bewijsmiddel onrechtmatig is verkregen kan slechts worden beantwoord in het licht van de rechtsverhouding tussen partijen. Daarbij speelt ook de redelijkheid en billijkheid een rol.

In de tweede zaak ging het om een allimentatievordering van de vrouw tegen haar gewezen ech tgenool. De vrouw had een door haar via de officier van justitie ontvangen fiodrapport betreffende door de man verzwegen inkomsten in het geding gebracht, waarna het Hof bij zijn beslissing van de gegevens uit dit rappost gebruik had gemaakt. Het cassatieberoep tegen de beslissing van het Hof werd verworpen. Met name oordeelde de Hoge Raad dat art. \& EVRM, een bepaling gericht op de bescherming van het privé-leven, uitzonderingen toelaat bij de wet ter bescherming van de rechten vati anderen. Nu de vrouw anspraak kon maken op de juiste gegevens betreffende het inkomen van de man, speelde de vraag of zij op correcte wijze in het bezil was gekomen van deze gegevens geen beslissende rol nu dit geval viel onder de in art. 8 EVRM genoemde uitzonderingen. Hieruit kan worden afgeleid dat wanneer iemand gegevens tot het bewijs wil laten meewerken, warap hij geen enkel recht kan doen gelden en hij deze gegevens bovendien op onrechtmatige wijze heeft verkregen, er sprake is van strijd met een behoor- 
lijke procesorde, zodat de rechter dergelijk bewijs buiten beschouwing moet laten.

Een wolgend punt warbij sprake is van prealabale watardering betreft de gelding van bewijsovereenkomsten of bewijsbedingen in algemene voorwarden.

Art. $189 \mathrm{R} v$ bepaalt dat bewijsovereenkomsten in twee gevallen buiten toepas sing blijven, namelijk wanneer het om rechisgevolgen gaat die niet ter vrije beschikking van partijen staan en wanneer het in strijd zou zijn met de goede trouw zich op de overeenkonst te beroepen.

Als rechtsgevolg dat niet ter vrije beschikking van partijen staat kan onder meer worden genoemd het ingaan tegen bepalingen van dwingend recht. bijv. wanneer de wet een bepaald bewijsmiddel bij uitshiting voorschrijt. Voorts kan de beperkende werking van redelijk heid en billijkheid zoals neergelegd in art. $6.5 .3 .1 \mathrm{lid} 2 \mathrm{NBW}^{11}$, er toe leiden dat aan een bewijsovereenkomst geen gevolg kan worden gegeven. Deze beperkende werking geldt echter slechts in marginale gevallen, al is hier uiteraard sprake van een open norm.

In afdeling 3 van Boek. 6 'Algemene voorwaarden' wordt in art. 236 (6.5.2. A 3 sub k) als onredelijk bezwarend beding genoemd het uitsluiten of beperken wan de bevoegdheid van de wederpartij van de gebruiker om bewijs te leveren of het wijzigen van de wettelijke bewijslastverdeling in zijn nadeel.

Is de regeling van de algemene voorwarden toepasselijk, dan zal de rechter desgevraagd met een onredelijk bezwarend beding geen rekening honden.

Daarmee zijn wij toegekomen aan de wettelijke regeling van de bewijsiastverdeling, zoals deze us neergelegd in art. $177 \mathrm{Rw}$.

Terwijl art. 1902 BW oud uitging van de zogenaamde affirmatieve bewijsleer, kort gezegd, wie stelt moet bewijzen, is door de $H R$ bij artest van 23 april 1976, in navolging van hetgeen reeds eerder door Eggens, Anema en Star Busmann was geleerd, beslist dat niet de normale gang van zaken behoeft te worden bewezen, doch integendeel hetgeen in afwijking daarvan wordt gesteld. ${ }^{12}$ Deze beslissing is sindsdien nog enkele malen herhaald. Zij houdt eer duidelijke nuancering in van de strikt aftirmatieve bewijsteer, watdoor de bewijspositie van de eiser tegenover een ontkennende gedaagde is vergemakkelijkt.

De formulering van art. 177 Rv vormt een compromis tussen de billigkeidsw leer, waarn de rechter de vrijheid heeft de bewijslast naar billyjk heid te verdeten en de objectiefrechtelijke leer, die inhoudt dat in beginsel hei materiele recht bepialt bij wie de bewijslast ligt. Het artikel bepaalt namelijk dat uitzonderingen op de hoofdregel mogelijk zijn wanneer zulks uit een bijzondere regel, of uit de cisen van redelijkheid en billijkheid voortvloeit.

Bij de parlementaire behandeling van het artikel is de vrag gesteld of an de rechter niet een motiveringsplicht zou moeten worden opgelegd in die gevallen waran hij op grond van redelijkheid en billijkheid de bewijskast anders verdeelt dan uit de hoofdregel volgt. De minister stelde dat de motiveringseisen dic hier gelden dezelfde zijn als die welke gelden bij toepassing van redelijkheid en 
billikheid in het algemeen, zodat or geen aanleiding was om hier een bijzondere moljyeringsplicht aan te nemen.

Nu bepaalt art. 3.1.1,13 NBW (3:12) dat bij de vaststelling van wat redelijkheid en billikheid eisen rekening moet worden gehouden met algemeen erkende rechtsbeginselen, met de in Nederland levende rechtsovertuigingen en met de matschappelijke en persoonlijke belangen die bij het gegeven geval zijn betrokken. Dit betekent dat de rechter die bij de werdeling van de bewijslast een beslissing nat billijkid moet geven met tal van objectieve factoren rekening moet houden en dat hij de maatschappelijke belangen en de persoonlijke belangen wan partijen tegen elkaar moet afwegen. Deze belangenwaardering dient te geschieden in het licht wan de rechtsverhouding tussen partijen in het geding. ${ }^{13}$

In het algemeen zal de rechter zich derhake in zijn vonnis uitdrukkelijk rekenschap moeten geven wan de rechtsgrond van zijn beslissing.

Daamee zijn wij toegekomen aan de vraag hoe het zit met de vrijheid van bewijswalardering bij de afzonderlijke bewijsmiddelen. Hierbij moet worden wermeld dat volgens waste rechtsprak van de Hoge Raad de waardering van bewiss is voorbehouden aan de rechter die over de feiten oordeelt. ${ }^{14}$ Achtereenvolgens zullen aan de orde komen het schriftelijk bewijs, het getuigenbewijs en het deskundigenbericht.

Schriftelijk bewijs verschilt in zoverre van mondeling bewijs dat het door partijen vooraf is vastgelegd, vandaar de benaming preuwe préconstituée. Van een ondertekend geschrift matg in het algemeen worden aangenomen dat bij de ondertekenaar de bedoeling voorzat een bewijsmiddel te verschaffen. Wordt die bedoeling aangevochten, dan zal het onder meer van het bij de wederpartij opgewekte vertrouwen afhangen of de ondertekenaar aan zijn verklaring wordt gehouden.

Terecht wordt in het commentaar van Veegens-Wiersma opgemerkt dat behalve de bewijsstemming ook de in een geschrift uitgedrukte wilsverklaring dit geschrift tot een akte makt. Aan een schriftelijk aanbod of de schriftelijke atanwaurding van een a anbod, hoewel niet noodzakelijk met de bedoeling geschreven on tot bewijs te dienen, zal door de rechter vrijwel steeds dwingende bewijskrach worden toegekend.

De last van het tegenbewijs dat met de verklaring iets anders werd bedoeld zal vrijwel steeds op degene rusten van wie de verklaring afkomstig is. Daarbij speelt uiteratrd de rechtsbetrekking ussen partijen een belangrijke rol.

Onder het oude bewijsrecht bepaalde art. 1907 dat een authentieke akte volledig bewijs oplevert van deszelfs inhoud terwijl art. 1912 hetzelfde inhield met betrekking tot een erkend onderhands geschrift. Uiteraard was de bewijskracht beperkt tot de partijen, hun erlgenamen of rechtverkrijgenden. In het nieuwe bewijstecht is sprake van een andere terminologie. Art. 183 lid 1 Rv stelt als definitie voorop: akten zijn ondertekende geschriften, bestemd om tot bewijs te dienen. 
Art. 184 lid I vervolgt dan met te bepalen dat authentieke ak ten tegen eenieder dwingend bewijs opleveren van hetgeen de ambtenaar binnen de kring wan zijn bewoegdheid omtrent zijn waarnemingen en verrichtingen heef verklatard. Partijverklaringen leveren slechts tussen partijen dwingend bewijs op van de waarheid dier verklaringen, tenzij dit zou leiden tot een rechtsgevolg dat niet ter vrije beschikking van partijen staat. Dit geldt zowel voor partijverklaringen in authenticke als in onderhandse akten.

Volgens art. $178 \mathrm{R}$ w houdt het begrip 'dwingend bewijs' in dat de rechter verplicht is de inhoud wan een bewijsmiddel als war aan te nemen dan wel de bewijskracht daarwan te erkennen. Volgens het tweede lid vat het artikel staat echter het leveren van tegenbewijs vrij tenzij de wet het uitsluit. Hieruit volgt dat elk bewijsmiddel als tegenbewijs tegen akten kan worden gebezigd zodat de rechter wederom vrij is in zijn waardering wan het tegenbewijs. ${ }^{15}$

Uiteraard betekent dit een relativering van de betekenis van de dwingende bewijskracht van akten.

Naast akten als geschriften met een specifieke bewijsstemming zijn er andere geschriften die niet als zodanig gelden. Veegens-Wiersma omschrijft het begrip geschrift-niet-akte als ieder voorwerp dat door middel van verstaanbare leestekens een gedachteninhoud vertokt maar dat noch als onderhandse, noch als authentieke akte kan worden aangemerkt. ${ }^{16}$

Onder deze ruime omschrijving valt derhalve alles wat hetzij in handschrif hetzij in druk is opgemaakt. De rechter is vrij in zijn waardering van de bewijskracht van geschriften-niet-akten. Daarbij is uiteraard van belang de processuele houding van de partij te wiens laste het geschrift in het geding wordt gebracht. Een gemotiveerde betwisting zal in het algemeen voldoende zijn on te bereiken dat het stuk niet zonder samenhang met andere bewijsmiddelen tot bewijs kan strekken. In dit verband ligt de vergelijking voor de hand met een bepaling als art. 344 lid 1 sub 5 Sv, inhoudende dat andere geschriften slechts in verband met de inhoud van andere bewijsmiddelen voor thet bewijs gebruikt mogen worden. Bij de parlementaire behandeling van art. $179 \mathrm{R} v$ is zoals eerder vermeld door enkele leden wan de D'66-fractie de vragg gesteld of het geen a anbeveling zou verdienen in de wet op to nemen dat het bewijs van enig feit waarvan de beslissing in een zaak rechtstrecks afhangt, niet geleverd kan worden door slechts ëen bewijsmiddel met uitsluitend vrije bewijskracht. De minister wees deze suggestie wan de hand met de opmerking dat daarmee het gehele system van vije bewijswatdering zou worden onder. graven. De rechter, aldus de minister, moet zeer wel in stat worden geacht ande hand van de onstandigheden van het geding te beoordelen en te beslissen of er voldoende grond aanwezig is het bewezen zijn van een betwist feit aan te nemen op grond van éen bewijsmiddel van welke aard dan ook. Bepalingen betreffende in de wet geregelde bewijsmiddelen kunnen, ald us de minister, eventueel analogisch worden toegepast op die middelen die in het geheel niet zijn geregeld."

De analogie met schriftelijk bewijs ligt hierbij voor de hand, met name voor wat 
betreft de beoordeling van de echtheid. Duarnaast moet uiteraard gewezen worden op de mogelijk heid tegenbewijs te leveren.

Een aanbod tegenbewijs te leveren tegen ander bewigs dan getugerbewijs moet conereet en specifiek zijn. ${ }^{18}$ Dit betekent wel dat de belanghebbende partij in de gelegenheid moet zijn geweest tegenbewijs aam te bieden. Indien een bewijsplichtige partij in het laatste gedingstuk nog een stuk produceert waaraan bewijs kan worden ontleend, moet de wederpartij in de gelegenheid worden gesteld zich daarover uit te laten.

Samenvattend kan gesteld worden dat er ondanks de dwingende bewijskracht wan schriftelijk bewijs in een aantal gevallen sprake is van warderingsmomenten. Wordt de bewijsbestemming van een akte betwist, dan is deze betwisting alan vrije bewijswatardering onderworpen.

In wezen is hier sprake van het leveren wan tegenbewijs tegen de akte. Toch komt het onjuist woor hierbij dezelfde beoordelingsvrijheid wan de rechter aan te nemen als ten aanzien van geschriften-niet-aktem. De bewijskracht van akten, en daarmee de rechtszekerheid, zou anders al te gemakkelijk worden ondermijnd. Een beslissing een akte niet tot bewijs te laten meewerken vraagt om een uitdrukkelijke motivering.

Bij geschriften-niet-akten in de ruime zin speelt allereerst de vraag in hoeverre het stuk rechtmatig is verkregen dan wel in het geding gebracht. De rechter zal hierbij zonodig moeten toetsen aan de grondrechten c.q. verdragsrechten, aan algemene rechtsbeginselen en de beginselen wan een behoorlijke procesvoering.

Met betrekking tol de bewijskracht van dergelijke stukken speelt, met name wanneer deze niet door ander bewijs worden versterkt, de waardering van de rechisverhouding van partijen een grote rol.

Daarmee zijn wij toegekomen aan de waarderingsmomenten bij getuigenbewijs.

De klassicke regel 'én getuige, geen getuige', art. 1942 oud BW, is in het nieuwe bewijsrecht niet opgenomen. Verder is de onbevoegdheid om te getuigen, de regel neergelegd in art. 1947 oud BW, argeschaft. Art. $191 \mathrm{Rv}$ bepaalt thans dat ieder, dus ook de procespartij, verplicht is desgevraagd getuigenis af te leggen. Wel zijn in een antal gevallen verschoningsrechten erkend doch deze gelden niet voor de procespartij als getuige.

Voor ons onderwerp van belang zijn de bepalingen die betrekking hebben op de warardering van getuigeverklaringen. De bepaling van art. 1943 oud $\mathrm{BW}$, speciaal woor her getuigenbewijs geschreven, is niet opgenomen, doch thans geldt de algemene regel van art. 179 lid $2 \mathrm{Rv}$, die de waardering van het bewijs aan de rechter overlat tenzij de wet anders bepaalt.

De getuigeverklaring, aldus art. $189 \mathrm{Rv}$ kan slechts als bewijs dienen ten aranzien van feiten die de getuige uit eigen warneming bekend zijn. Het begrip eigen waarneming dient ruim te worden opgevat, zodat daaronder ook valt 
hetgeen een getuige iemand anders heeft horen verklaren, alsmede de indruk die een getuige persoonlijk kreeg tijdens zijn waameming."

De belangrijkste wettelijke beperking bij de watardering van de bewijskracht van getugeverklaringen heeft betrekking op de partij-getuige. Volgens art. 213 Rv kan de verklarng van deze getuige omtrent door deze partij te bewijzen feiten geen bewijs ten haren voordele opleveren, tenzij de verklaring strekt ter annvulling van onvolledig bewijs. De rechter is echter wel weer vrij in zijn waardering van de aanwezigheid van een begin van bewijs.

Door H. Stein is destijds de vrees geuit dat het criterium door een partij te bewijzen feiten' tot grote onzekerheid zal leiden. ${ }^{2 k}$ De formulering van de bewijsopdracht biedt namelijk geen zekerheid, ondat volgens HR 25 november 1966 de formulering van een bewijsopdracht door de rechter slechts een voorlopig karak ter heeft waaraan de rechter in het verdere geding niet gebonden is. De rechter zou dus door in het eindvonnis van de bij tussenvonnis gegeven bewijsopdracht af te wijken volgens Stein de wettelijke beperking van de bewijskracht van de werklaring van de partij-getuige kunnen afzwakken.

Deze uitlleg van art. $213 \mathrm{Rv}$ acht ik onjuist. De rechter zal immers moeten nagaan in hoeverre de woor zijn eindbeslissing relevante feiten zijn komen vast te staan. Ingevolge art. 213 Rv mogen deze feiten met als vaststaande worden aangenomen uitsluitend op grond van de verklaring van de bewijsplichtige partij.

De vraag wanneer er sprake is van een begin van bewijs kan slechts worden beantwoord in het licht van de rechtsverhouding tussen partijen en het tussen hen gevoerde debat. De rechter die als zijn oordeel uitspreekt dat er een vermoeden is ten gunste van een bepaald standpunt, zal zich hiervan in het vonnis rekenschap dienen te geven.

Een belangrijk waarderingsmoment is voorts gelegen in de beslissing over het aanbod van een procespartij tot het leveren van getuigenbewijs. De beslissing over de vraag of het bewijsaanbod ter zake dienende is dan wel of dit als te vaag moet worden beschouwd, is overgelaten aan de feitelijke rechter. De rechter mag echter niet een bewijsanbod passeren op grond van een negatieve verwaching omtrent het resultaat wan een getuigenwerhoor. ${ }^{21}$ Voorts dient het passeren wan een bewijsaanbod te worden gemotiveerd. ${ }^{22}$ Deze motivering kan in cassatie marginaal worden getoetst. Zo verwierp de $H R$ bijarrest van 13 januari 1978, NJ 1978, 302, de motivering wan het Hof dat een bewijsambod diende te gepasseerd nu daarin niet was aangegeven wat ieder van de getuigen zou kunnen verklaren. omdat dit volgens de HR rechtens niet van een partij kan worden gevergd.

Ook met betrekking tot een aanbod van tegenbewijs mag niel de eis gesteld worden dat daarbij nauwkeurig de zakelijke inhoud van de door de getuige af te leggen verklaring wordt aangegeven. ${ }^{23}$

De rechter is niet verplicht ambtshalve bewijs op te dragen, ook niet wanneer hij recht doet op grond wan vermoedens, ontleend aan waarnemingen ter terechtzitting. ${ }^{24}$ 
Wardering van bewijs ten slote mag zich niet uitstrek ken tol de geloof warardigheid wan nog niet gehoorde getuigen.

Bij de wardering van getugenverklaringen gat het enerzijds on de relevantie, anderzijds on de geloofwaardigheid. Reletantie heeft niet alleen betrekking op het bewijsthema. In de eerste plats heef het bewijsthema zoals dit in de bewijsopdracht is geformuleerd als vermeld slechts voorlopige betekenis. Mededelingen van cen getuige die op het eerste gezich weinig of niets met het bewijsthema te maken hebben, kurnen achteraf wel degelijk van belang blijken voor de beslissing in de zaak. Relevantie kan daarom beter betrokken worden op de rechtsverhouding in geding in de ruimste zin van het woord.

In de lweede plaats kunnen mededelingen van getuigen iets zeggen ower hun geloofwas rdigheid en darom kunnen zij van belang zijn bij de waardering van de verklaring. In zoverre zijn deze mededelingen dus wel degelijk relevant, ook al zijn zij van weing belang voor het bewijsthema.

Er zijn twee onstandigheden die de geloofwaardigheid van cen getuige nadelig kunnen beinvloeden, te weten vooringenomenheid of wel gebrek a an onpartijdighoid en (financicel) belang bij de afloop van het geding.

Een onpartijdige getuige betoont ten opzichte van beide partijen in het geding dezelfde afstandelijkheid, maar een dergelijke onpartijdigheid komt zelden voor. Ook al geeft een getuige blijk van meer sympathie voor het ene standpunt dan voor het andere, dil behoeft nog geen reden te zijn hem te wantrouwen. Het kan immers heel goed zijn dat een getuige door zijn betrokkenheid bij de zaak terecht overtuigd is wan de juistheid van een bepaald partijstandpunt. Het komt er dan vooral op aan dat hij zijn verklaring met redenen van wetenschap omkleedt. Vergist een getuige zich op een punt, dan sluit dit betrouwbaarheid op andere punten nog niet uil.

Er is al opgemerkt dat de walardering van getuigeverklaringen is voorbehouden ande rechter die over de feiten oordeelt. ${ }^{25}$ De rechter kan daarbij vrijelijk kiezen wit onderling afwijkende verklaringen en zelfs de voorkeur geven aan een buiten rechte afgelegde verklaring.

De vulag die hierbij rijst is die hover de motiveringsplicht van de rechter zich uistrekt. De motiveringseis is te vinden in art. 59 derde lid Rv, mar er is at opgemerkl dat voor zo ver het reitelijke beslissingen betreft, deze in cassatue slechts zeer marginat worden getoetst. Het is dan ook vooral de appelrechter die behoefte heef an een verantwoording van feitelijke beslissingen door de rechter in eerste analeg.

Een bepaling als art. 1945 oud $\mathrm{BW}$ watrin aan de rechter een aantal richtlijnen werden gegeven voor de beoordeling van de warde van getuigeverklaringen, ontbreekt in het nieuwe bewijsrecht. Alleen de bepaling van art. 189 Rv geeft in zoverte enige steun dat deze de rechter verplicht voor het bewijs alleen gebruik te maken van de getuige uit eigen waarneming bekende feiten.

De wetgever heeft woor het overige alles aan de vrije watdering van de rechter 
overgelaten en de wet verplicht de rechter niet in zìn vonnis uitwoerig rekenschap te geven van het warom van zijn keuze. ${ }^{26}$ De Hoge Raad eist slechts dat uit de weergave van de bewijsmiddelen in het vonnis de door de rechter gegeven beslissing kan worden gerechtvaardigd ${ }^{27}$

De beslissing moet begrijpelijk zijn en vrij zijn van innerlijke tegenstrijdigheden. Daarbij komt het er vooral op ann dat de rechter op gemotiveerde bezwaren van een procespartij tegen de inhoud van cen getuigeverk laring ingaat en deze bezwaren zonodig weerlegt.

Ook bij de bewijswaardering stat de gelijk heid wan partijen in het burgerlijk proces voorop. De opmerking van Hidma dat de rechter iets niet bewezen mag verklaren ook al verklaren 100 getuigen het woor waar ${ }^{28}$ acht ik dan ook minder gelukkig. Hoe meer bewijs er voor een bepald standpunt is te vinder. des te zwatardere eisen mogen worden gesteld aan de motivering waarom van dit bewijs geen gebruik wordt gemakki.

Daamee zijn wij toegekomen aan het laatste onderded, de watrdering van het deskundigenbericht. Hoewel een bepaling als art. $2360 u d \mathrm{Rv}$, inhoudende dat de rechter niet verplicht is de conclusie van deskundigen te volgen. niet in het nieuwe bewijsrecht is overgenomen, volgt uit de algemene regel van art. 179 lid $2 \mathrm{Rv}$ dat ook met betrekking tot het oordeel van deskundigen de fechter vrij is in zijn waardering, tenzij de wet anders bepaalt.

Volgens art. 224 lid 2 Rv kan de rechter als hij dool hel schriftelijk bericht of mondeling verslag onvoldoende is ingelicht nadere inlichtingen vragen of andere deskundigen benoemen doch hij is daartoe niet verplicht. ${ }^{24}$ Wel wordt algemeen aangenomen dat de rechter, indien hij het oordeel van desk undigen niet volgt, zijn beslissing dient te motiveren. ${ }^{30}$

Uiteraard kumen partijen overeenkomen dat een uitsprak van deskundigen voor hen als bindend advies zal gelden, in welk geval ook de rechter daaraan is gebonden, tenzij dit bindend advies op grond van een beroep op redelijkheid en billijkheid terzijde wordt gesteld.

De motivering door de rechter van zijn beslissing dat hij het gevoclen wan de deskundige niet volgt, kan aanleiding geven tot een klacht in cassatic wegens zogenaamde motiveringsgebreken, mel name wanneer de rechter zich daarbif verwijdert wan hetgeen ten processe vaststat of wanneer zijn gedachtengang niet vrij is van tegenstrijdigheden.

De rechter die afwijkt van een deskundigenbericht zal er goed aan doen zijn oordeel zo mogelijk te onderbouwen met argumenten die ontleend kunnen worden aan tussen partijen vaststaande reiten. Spreken deskundigen elkatar legen of verwijderen zijzich van de feiten, dan kunnen ook die gegevens steun geven aan de beslissing het oordeel van deskundigen niet te volgen.

Samenvatting. In het nieuwe bewijsrecht is sprake van een open systeern wan bewijsmiddelen met ats hooforegel dat de rechter vrij is in zijn waardering van de 
bewijkracht van voorhanden zijnde bewijsmiddelen, behoudens in de wet genoende uitzonderingen, warvan de belangrijkste zijn de bewijkracht wan akten en die wan de verklaring wan de partij-getuige. Omdat de rechter wrij is in zijn waardering van tegenbewijs en begin van bewijs, zal de incidentele gebondenheid van de rechter hem slechts zelden tot en beslissing dwingen die hij, als hij niet gebonden zou zijn geweest, niet zou hebben gegeven.

De wrees dat de waarderingswriheid van de rechter ten koste gaat van de rechtszekerheid behoeft niet te worden gedeeld, mits de rechter, telkens wanneer het debat tussen partijen daartoe aanleiding geeft, zijn keuze voor of tegen het gebruik van een bewijsmiddel zodanig motiveert, dat zijn gedachtengang woor de procespartijen begrijpelijk is.

Voor zover het oordeel van de rechter zuiver feitelijk is, kan dit alleen in hoger beroep worden getoetst.

Is er sprake van rechtsbeslissingen zoals die betreffende toelaatbaarheid van bewijs, dan is ook toetsing in cassatie mogelijk.

Ik dank U voor Uw andacht. 
1. Lana-Eggens, Verklaring wan het Burgerligk Wetboek. 193,3 Wh, p. 12 .

2. Asser-Anema-Verdam. Van Bew js. 50 druk, 1953 . p. 35.36.

3. S. Gerbrandy. Het watheidsproblaen in het procespeh. Handelingen van de Verenging woor Wijbegeerte des rechs. 1961. 1. p. 27.

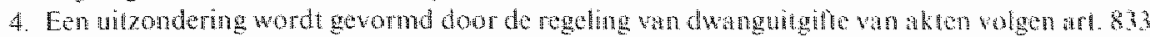

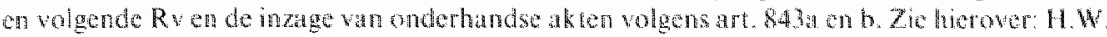

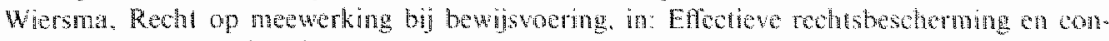
stintionele rechisorde. Teenk Willink Zwolle. 1984, p. 79 e.

5. H. Drion. Bewijzen in het rech. Themis 1966, p. 414

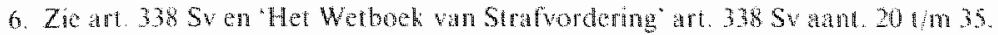

7. Kamersukkern wetsontwerp $1037 \%$, nr. 12, p. 10 en m. 13. p. 26.

8. Zie onder meer Dijksterhuis-Wien. Bewijsecht in civele procedurs, Kluwer $198 \%, p, 32$.

9. Burgerijke Rechtsvordering 1, atd an 179, p. 383 .

10. HR 1 juli 1982. NI 1983,682 en 23 mei 1986 . NJ1987, 702 .

1. In de definieve nummering art. 6.248. In het vervolg zal deze nummering steds tussen hatajes worden wermeld.

12. HR 23 april 1976. NI [977. 47 (v.d. Mecr/Hellangah.

13. Vel. P.A. Stem, De verdeling van de bewijglast, in: Niets dan de whatheid, Jonge Batio congresbundel 1988, Tjeenk Willink Zwolle, 1988, p. 56.

4. HR 15 fobruari 1977. NJ 1977, 557; HR 23 decomber 1980. NI 1981, 484; HR 21 oktober 1988. NJ 1989. 102. Vgl. condusie A.G Ten Kate.

15. Veegens-Wiersma. Het neuwe bewijsechn in burgenlike zaken, 2. Tjenk Willnk Zwolle. 1988. Jar. 33

16. Vegens-Wiersma, 4.a.p. ar. 18 .

17. Punl Geschiedenis ad ant. 179 Rv. p. 102.

18. HR 17 nowember 1967. NJ1968, 30 (H.D.).

19. Dijksterbuis-Wieten. A.ap. p. 96 en de das genoende jurisprudentic.

20. H. Stein, Advocatenblat 24 janduri 1986 , p. 29 e.v.

21. HR 24 november 1961. NI 1962, 22; HR 23 december 1966. NJ1967,86; HR 10andustus 1988. NI1989.8.

22. HR 3 rebruari 1967 , NI 1968,30 en 32 (D.J.V.).

23. HR 31 oktober 1980, NJ 1981, 195: HR 25 februari 1983, N.1983.630: HR 9 moi 1980. N.11986, 608 .

24. HAR 19, juni 1987. NJ 1988, 296.

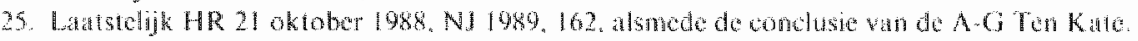

26. Kluwer Rw, I, ad ant 59 , anat. 13.

27. HIR 27 nowember 1941, NJ 1982.263.

28. Pillo-Hidma, bedruk, 1981, p. 23.

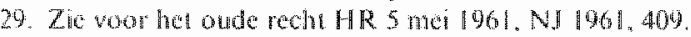

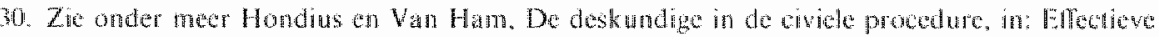

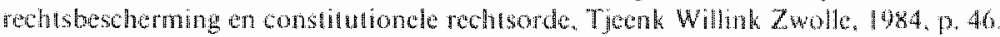

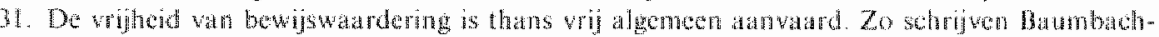

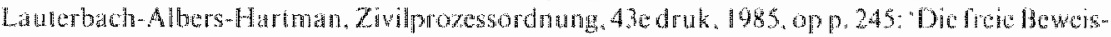

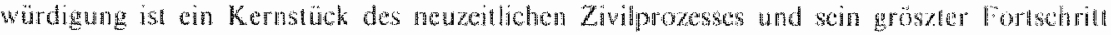

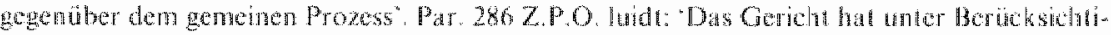

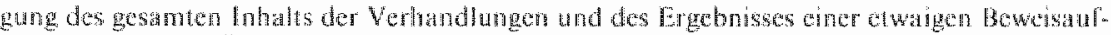
nathe nach freier Uberzeugung za entscheden obeno tatsobliche Behauplung lür wath oder

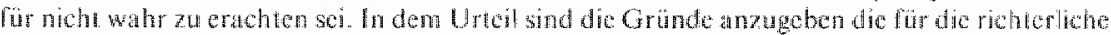
Oberzeugung leitend gewesern sind 
En A. Keane schrift: "The assestment of the weigh of evidence is essernialy a matter of

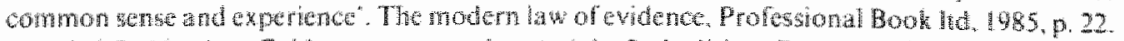

Vgl J.D. Hoydon, Evidence, cases and materals. 2nd adhon, Buterworh. 1984. B. 8.

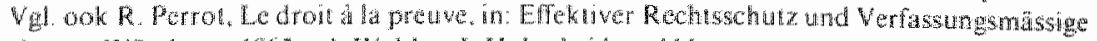
Ordnung. Whrburg. 1983. ed. Wrather J. Habsheid. p. HI e. 